\title{
EFFECT OF DAMP AND TREATMENT METHODS ON RESIDENTIAL BUILDINGS IN CALABAR METROPOLIS OF CROSS RIVER STATE
}

\author{
Stanley Emmanuel Ubi ${ }^{1}$, Paul Nkra Obun ${ }^{2}$, Agbor Reagan B ${ }^{2} \boldsymbol{\mathbb { U }}$, Thankgod Tom ${ }^{1}$, \\ Monday Agbor 1 \\ ${ }^{1}$ Department of Civil Engineering, Cross River University of Technology, CRUTECH, Calabar, \\ Nigeria \\ ${ }^{2}$ Environmental Biotechnology Unit, Department of Genetics and Biotechnology, University of \\ Calabar, Calabar, Nigeria \\ ${ }^{3}$ Department of Works, University of Calabar, Nigeria
}

DOI: https://doi.org/10.29121/granthaalayah.v8.i8.2020.1206

Article Type: Research Article

Article Citation: Stanley Emmanuel Ubi, Paul Nkra Obun, Agbor Reagan

B, Thankgod Tom, and Monday Agbor. (2020). EFFECT OF DAMP

AND TREATMENT METHODS ON RESIDENTIAL BUILDINGS IN CALABAR METROPOLIS OF CROSS RIVER STATE. International Journal of Research -GRANTHAALAYAH, 8(8), 372-376.

https://doi.org/10.29121/granthaa layah.v8.i8.2020.1206

Received Date: 18 August 2020

Accepted Date: 31 August 2020

Keywords:

Damp

Treatment

Residential

Buildings

\section{ABSTRACT}

The main purpose of this study was to investigate the effect of damp and treatment methods on residential buildings in Calabar Metropolis of Cross River State. Damp is a pervasive problem for residential buildings. It is at times expressed in the most unlikely places under unexpected and unsettling conditions due to heavy rainfall. It is usually expressed at home, market, and neighborhood or within community. At different-occasions damp had cause many damages to school properties, destruction of roads especially during rainy season. To achieve the purpose of this study two research questions were formulated to direct the study. Survey research design was adopted for the study. A sample of one hundred respondents was randomly selected for the study. The selection was done through the simple random sampling technique. This was to give equal and independent opportunities to all the respondents to be selected for the study. The questionnaire was the instrument used for data collection. The instrument was subjected to face validation by experts in measurement and evaluation. The reliability estimate of the instrument was established through the test re-test reliability method. The results of the respondents reveal that damp and treatment method significantly influence residential buildings in Calabar Metropolis. Based on the findings, it was recommended among others that the State government should construct good drainage system to enhance the free flow of stagnant water during or after rainfall in order not to cause damages to the buildings.

\section{INTRODUCTION}

Damp is a pervasive problem for Calabar Metropolis. Most at times it occurred unexpectedly when there is heavy down-pour. Dampness is the presence of unwanted moisture in the structure of a residential or commercial building, it occurs mainly in old buildings, either the result of water over running from outside or condensation from within the structure. Moisture in buildings is a major contributor to mold growth, unhealthy buildings, and poor indoor air quality. A high proportion of damp problems in buildings are caused by ambient climate dependent factors of condensation and rain penetration (Prowler 2011). Dampness in buildings can damage much more than a buildings

(C) 2020 The Author(s). This is an open access article distributed under the terms of the Creative Commons Attribution License, which permits unrestricted use, distribution, and reproduction in any medium, provided the original author and source are credited. 
appearance. It may lead to deterioration of plaster and masonry, promote timber decay and create unhealthy condensation (Oliver 2017). Dampness tends to cause secondary damage to a building. The unwanted moisture enables the growth of various fungi in wood, causing rot or mold health issues, could eventually lead to sick building syndrome. Molds can grow on almost any surface and occur where there is a lot of moisture from structural problems such as leaky roofs or high humidity levels. One of the most important requirements of a building is that it should remain dry, that is, damp proof. In the event that this condition is not fulfilled, all things considered, the structure may get unhygienic to the occupants and dangerous from the structural perspective, since dampness breeds germs of specific illnesses and deteriorates the structure. Damp in building can occur naturally when the foundation of a building is not well treated with the appropriate material which may lead to rising damp. Burkinshaw and Parrett (2004), explained that a building can be described as having a dampness effect or problem when the materials contained in that building becomes sufficiently damp to cause material damage and visible mold growth. Hall et al., (2011), noted that damages to structures brought about by dampness represent a genuine risk to the performance of the structure and infiltration of dampness/moisture through the fabric of structures over some undefined time frame and is typically described by localized regions of damp or immersed wall/ceiling finishes. Alfano etal. (2006), ascertained that damp in building can be caused by bad eaves or inadequate gutters or cracked roofing tiles, broken pointing, improper wall thickness, poor construction and inadequate protection. However, when considering the causes of damp we should know that damp occur in different means which are condensation, rain penetration, rising damp and humidity. Beal (2000), consider the concurrent event of the presence of water, an opening through which water can enter and a physical power to move the water are the three primary issues that support water infiltration through a structure enclosure. Ralf (2008), describes damp as a level on the external envelop of a building which are liable to moisture effects caused by pooling or splashing or impinging of (usually) rain water at the junction of a horizontal surface to the vertical wall surface-being most common at the wall base. In line with the above, Broady (2019), opines that condensation is caused when the vapour of water inside a structure can move outward by means of diffusion through permeable structure fabric or air development and arrive at a surface inside the structure cavity that is underneath the dew point. That surface might be smooth, for example, sheet metal, or fibrous, for example, glass wool insulation. A cold surface that gathers vapour assimilates the warmth of vaporization, raising its temperature marginally. In this manner condensation can be generally quick on a metal frame, and less fast on an insulation material. Be that as it may, given time, both may condense a considerable amount of water. Interstitial condensation can be definitely more harming to the structure than surface condensation. Interstitial condensation can go unnoticed and if the structure fabric has not been intended to enable dampness to dry from inside, it can get caught and compromise the strength/durability of the structure and the wellbeing of the inhabitants. However, building with poorly insulated walls is very prone to this problem. It regularly causes harms like damp in a structure and frequently shows up in comparative spots. Damp gathers on the inside of the structures because of explicit communications between the rooftop and walls. In Cross River State, damp has been a major issue which affects buildings. Damp has put the life of occupant, at risk and causing health problems such as asthma, it causes damage to their properties and also the deterioration of building. However, the problem of damp in the buildings occur when there is a lot of moisture in the structure, such as leaky roofs or high humidity levels whereby mortar or plaster may fall away from the affected wall, causing a poor indoor air quality and respiratory illness in occupants. Hence there is need to find out the causes, prevention and treatment of damp in buildings.

\section{MATERIALS AND METHODS}

The research design used for this study was Survey research design, through the use of observation with the aid of checklist and visual inspection. This was carried out in order to describe the observable fact or occurrence the way they are manifested in natural settings and buildings. The population of this study comprises of all the Landlord/Landladies in Calabar Metropolis of Cross River State of Nigeria. The sampling technique adopted for this study was the simple random sampling technique. One hundred (100) individuals were randomly selected from five communities in Calabar Metropolis. The main instrument used for data collection was the research questions designed by the researcher through the assistant of experts. The items in the research questions were drawn in reflection of the variables under study. Before using the instrument the items developed were given to experts in research and statistics for screening. To determine the reliability of the instrument, a trial testing was done using 
Effect of Damp and Treatment Methods on Residential Buildings in Calabar Metropolis of Cross River State twenty (20) respondents. Test re-test reliability method was used to determine the reliability coefficient of the instrument.

\section{RESULTS AND DISCUSSION}

The variables were identified and statistical analysis carried out to provide answers to the research questions. The 0.05 level of significance was used for the statistical testing of each research question.

\subsection{RESEARCH QUESTION ONE}

To what extent does damp affect residential buildings? To provide answer for this research question, data were gathered and analyzed as presented in Table 1.

Table 1: Responses of respondent of whether damp affect residential buildings in Calabar Metropolis of Cross River State.

\begin{tabular}{|c|c|c|c|c|c|}
\hline S/N & Item & Yes & No & $\%$ Yes & $\%$ No \\
\hline 1. & Does rain penetration affect residential buildings? & 14 & 6 & $70 \%$ & $30 \%$ \\
\hline 2. & Does rising damp affect residential buildings? & 18 & 2 & $90 \%$ & $10 \%$ \\
\hline 3. & Does condensation affect residential buildings? & 10 & 10 & $50 \%$ & $50 \%$ \\
\hline 4. & Does roof leakage significantly affect residential buildings? & 12 & 8 & $60 \%$ & $40 \%$ \\
\hline 5. & Does lack of drainage affect residential buildings? & 14 & 6 & $70 \%$ & $30 \%$ \\
\hline
\end{tabular}

The Table 1 above reveals that all the itemized columns are the causes of damp in the Calabar Metropolis of Cross River State.

It further indicated that 14 representing (70\%) of respondents agreed that rain penetration affect residential building; while 6 representing (30\%) of respondents do not. Again, 18 representing (90\%) of respondents agreed that rising damp affect residential building; while 2 representing (10\%) of respondents do not. Also, 10 representing (50\%) of respondents agreed that condensation affect residential building; while 10 representing (50\%) of respondents do not. More so, 12 representing (60\%) of respondents agreed that roof leakages significantly affect residential building; while 8 representing (40\%) of respondents do not. Finally, 14 representing (70\%) of respondents agreed that drainage affect residential building; while 6 representing (30\%) of respondents do not.

\subsection{RESEARCH QUESTION TWO}

How does treatment method impact to residential buildings? The data were gathered and analyzed in order to provide answer for the research question 2 as presented in Table 2.

Table 2: Responses of respondent of whether treatment method has any impact on residential buildings in Calabar Metropolis of Cross River State.

\begin{tabular}{|c|c|c|c|c|c|}
\hline $\mathrm{S} / \mathrm{N}$ & Item & Yes & No & $\%$ Yes & $\%$ No \\
\hline 1 & $\begin{array}{l}\text { Does treatment of foundations against gravitational water has any significant } \\
\text { impact on residential buildings? }\end{array}$ & 13 & 7 & $65 \%$ & $35 \%$ \\
\hline 2 & $\begin{array}{l}\text { Does treatment of basements has any significant impact on residential } \\
\text { buildings? }\end{array}$ & 16 & 4 & $80 \%$ & $20 \%$ \\
\hline 3 & Is there any significant impact of floors treatment on residential buildings? & 12 & 8 & $60 \%$ & $40 \%$ \\
\hline 4 & Does treatment of walls has any significant impact on residential buildings? & 18 & 2 & $10 \%$ & $90 \%$ \\
\hline 5 & Does treatment of flat roofs has any implication on residential buildings? & 11 & 9 & $55 \%$ & $45 \%$ \\
\hline
\end{tabular}

In accordance to the above Table 2, it is clearly stated that all the itemized columns are the measure for treatment method in the Calabar Metropolis of Cross River State. 
However, based on individual responses, it was denoted that, 13 representing (65\%) of respondents agreed that treatment of foundations against gravitational water has significant impact on residential building; while 7 representing (35\%) of respondents do not. Again, 16 representing (80\%) of respondents agreed that treatment of basements has significant impact on residential buildings; while 4 representing (20\%) of respondents do not. Also, 12 representing $(60 \%)$ of respondents agreed that there is significant impact of floors treatment on residential buildings; while 8 representing (40\%) of respondents do not. Furthermore, 18 representing (90\%) of respondents agreed that treatment of walls has significant impact on residential buildings; while 2 representing (10\%) of respondents do not. Conclusively, 11 representing (55\%) of respondents agreed that treatment of flat roofs has great implication on residential buildings; while 9 representing (45\%) of respondents do not.

\section{DISCUSSION OF FINDINGS}

From the research paper it shows that the causes of dampness are link to factors such as rain penetration, rising damp, condensation, humidity, roof leakage and lack of drainage and this factors significantly affect residential buildings in Calabar Metropolis. In agreement to the finding, Alfano, et al., (2006) opined that rain penetration from the wall can be treated by providing adequate wall thickness or cavity walls, exposed wall faces should be of good quality and have a low water absorption capacity and covered with cement plaster. Similarly, Hutton (2011) asserted that condensation can be treated by increasing background heat, ventilation of cold surfaces, reducing moisture generation. In another finding, it revealed that treatment method has a significant impact on residential buildings among Calabar Metropolis dwellers. In line to the BMJ (1872), rising damp can be treated by replacement of physical damp-roof course, Injection of a liquid or cream chemical damp proof course (DPC Injection), Damp-proofing rods, Porous tubes/other evaporative, land drainage, electro-osmotic system and plastering. Godish (2001), also observed that roof leakages can be prevented when we pay attention to roof flashings. Without great, tight flashings around chimneys, vents, skylight, and wall or rooftop intersection, water can enter a home and cause harm to walls, ceiling, insulation and electrical framework. Hence, without legitimate ventilation, warmth and moisture develop can cause rafters and sheathing decay, shingles to buckle, and protection to lose its viability. Never block wellsprings of ventilation, for example, louvers, ridge vents or soffit vents. Legitimate air ventilation will help forestall auxiliary harm brought about by dampness and mold, increment roofing material life. Perry and Green (2007), also opined strategies to prevent humidity in structure is to make sure an activity as simple as cooking dinner, taking a shower, or doing a load of laundry doesn't invite mold by providing proper ventilation in your bathroom, kitchen, laundry room, and any other high-moisture area. So open the window when cooking or washing dishes or showering, or run an exhaust fan.

\section{CONCLUSIONS}

Dampness is a major contributing factor to building defection and it impact negatively on residential building, thereby reducing the life-span of the building and endanger the life of occupants. Based on visual inspection and interview carried out, the data showed that dampness exists in landed residential buildings. From this research paper it could be denoted that, factors like faulty construction method, poor construction materials, lack of maintenance and poor drainage system should be avoided, beginning from the pre-construction, during construction and post construction stage by the professionals involved to avoid dampness or any building defect. Problem associated with various forms of dampness and the necessary measures of treatment needed to pro-long the life span of a building were also disclosed.

\section{SOURCES OF FUNDING}

This research received no specific grant from any funding agency in the public, commercial, or not-for-profit sectors.

\section{CONFLICT OF INTEREST}

The author have declared that no competing interests exist. 
Effect of Damp and Treatment Methods on Residential Buildings in Calabar Metropolis of Cross River State

\section{ACKNOWLEDGMENT}

None.

\section{REFERENCES}

[1] Alfano, G; Chiancarella C., Cirillo E., Fato I., Martellotta F. (2006). "Long-term performance of chemical dampproof courses: Twelve years of laboratory testing". Building and Environment. 41 (8): 1060-1069. doi:10.1016/j.buildenv.2005.04.017

[2] Arora, S. P. and Bindra, S. P.; Dhampat Rai \& Sons (2010). A textbook of building construction. Civil Engineering Materials \& Construction. Code: BCE 203.

[3] Beal, L. M., Molinari, R. L., Chereskin, T. K. and Robbins, P. E. (2000). Reversing bottom circulation in the @Somali Basin. Geophysical Research Letters 27: doi: 10.1029/1999GL011316. ISSN: 0094-8276.

[4] British Medical Journal (1872). PMCID: PMC 2297280, 01 Mar, 1(583): 242-248.

[5] Broady, Thomas (2019). Damp problems: What can you do? www.chrisruddsolicitors.Co:UK. Chris Rudd Solicitors. Retrieved 8 March.

[6] Burkinshaw, R. and Parrett, M. (2004). Diagnosing damp in a tropical building: Applying Theory to practice. RICS Books, Coventry UK.

[7] Burkinshaw, R. (2008). Remedying damp. RICS Books. P.151. ISBN: 978-1-84219-305-1

[8] Fischer, Konrad. (2018). "Damp Wall \& Wet Cellar - Rising Damp Scam, Saltpeter \& Capillarity in Old Buildings - a Hoax of Moisture \& Salts". www.konrad-fischer-info.de. Retrieved -09-17.

[9] Godish, T. (2001). Indoor environmental quality. CRC Press. ISBN: 1-56670-402-2

[10] Hall, Christopher; Hamilton, Andrea; Hoff, William D; Viles, Heather A; Eklund, Julie A (2011). "Moisture dynamics in walls: Response to microenvironment and climate change". Proceedings of the Royal Society A. 467 (2125): 194-211. doi:10.1098/rspa.2010.0131

[11] Hutton, T. (2011). Rising damp. The building conservation directory. www.buildingconservation.com. Retrieved.

[12] Hutton, T (2011). "Rising Damp". www.buildingconservation.com. The Building Conservation Directory. Retrieved 21 November.

[13] Oliver A. (2017). Dampness in buildings. BSP Professional Books. ISBN: 0-632-01932-8.

[14] Perry, R. H. and Green, D. W. (2007). Perry's Chemical Engineers Handbook (8th edition) Section 12, Psychometry. Evaporative Cooling and Solids Drying. McGraw-Hill. ISBN: 978-0-07-151135-3

[15] Prowler, D. (2011). Mold and Moisture dynamics. WBDG: Whole building design guide. Retrieved 11 July.

[16] Schiavon, S. (2014). Adventitious ventilation: A new definition for an old model Indoor Air, 24(6): 557 - 558. Doi:10. 1111/ina.12155. ISSN: 1600-0668.PMID 25376521. 